\title{
Responses to Diuretic Treatment in Gene-Targeted Mice Lacking Serum- and Glucocorticoid-Inducible Kinase 1
}

\author{
Ferruh Artunc $^{\mathrm{a}, \mathrm{b}} \quad$ Ammar Ebrahim $^{\mathrm{a}}$ Balasaheb Siraskar ${ }^{\mathrm{a}}$ Omaima Nasir ${ }^{\mathrm{a}}$ \\ Rexhep Rexhepaj ${ }^{\mathrm{a}}$ Kerstin Amann ${ }^{\mathrm{c}}$ Bjoern Friedrich ${ }^{\mathrm{b}}$ Teut Risler $^{\mathrm{b}}$ \\ Florian Lang ${ }^{a}$
}

Departments of a Physiology and ${ }^{\mathrm{b}}$ Internal Medicine IV, University of Tübingen, Tübingen, and

'Department of Pathology, University of Erlangen, Erlangen, Germany

\section{Key Words}

Aldosterone $\cdot \mathrm{NaCl}$ cotransporter $\cdot$ Renal outer medullary

$\mathrm{K}^{+}$channel $\cdot$ Signal transduction $\cdot$ Transporters

\begin{abstract}
Background/Aims: Serum- and glucocorticoid-inducible kinase 1 (SGK1) stimulates the epithelial sodium channel (ENaC), renal outer medullary $\mathrm{K}^{+}$channel $1, \mathrm{Na}^{+} / \mathrm{K}^{+}$-ATPase and presumably the $\mathrm{Na}^{+}-\mathrm{Cl}^{-}$cotransporter (NCC). SGK1-deficient mice $\left(\mathrm{sgk}^{--}\right)$show a compensated salt-losing phenotype with secondary hyperaldosteronism. The present experiments explored the role of SGK1 in the response to diuretics. Methods: $s g \mathrm{k}^{-/-}$mice and their wild-type litter-

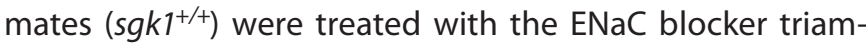
terene $(200 \mathrm{mg} / \mathrm{l})$, the $\mathrm{Na}^{+}-\mathrm{K}^{+}-2 \mathrm{Cl}^{-}$cotransport inhibitor furosemide $(125 \mathrm{mg} / \mathrm{l})$, the NCC blocker hydrochlorothiazide $(400 \mathrm{mg} / \mathrm{l})$ and the mineralocorticoid receptor blocker canrenoate $(800 \mathrm{mg} / \mathrm{l})$ for 8 days. Renal SGK1 expression was studied using quantitative RT-PCR and immunofluorescence. Results: Diuretic treatment increased SGK1 mRNA and protein expression in the kidney of wild-type $s g \mathrm{k}^{+/+}$ mice. The responses to furosemide, hydrochlorothiazide or canrenoate were not different between $s g \mathrm{k}^{+/+}$and $s g \mathrm{k}^{-/-}$
\end{abstract}

\section{KARGER}

Fax +41613061234 E-Mail karger@karger.ch www.karger.com (c) 2009 S. Karger AG, Basel

$1420-4096 / 09 / 0322-0119 \$ 26.00 / 0$

Accessible online at

www.karger.com $/ \mathrm{kbr}$ mice, and were accompanied by moderate increases in plasma aldosterone and urea concentrations. However, treatment with triamterene in $s g \mathrm{k}^{-/-}$mice (but not in $s g \mathrm{k}^{1^{+/+}}$ mice) led to severe, eventually lethal, body weight loss as well as increases in plasma aldosterone, urea and $\mathrm{K}^{+}$concentrations. Conclusions: SGK1 is required for diuretic tolerance to triamterene. The observations confirm the impaired kaliuretic potency of $s \mathrm{gk}^{-/-}$mice and point to a role of SGK1 in renal $\mathrm{Na}^{+}$reabsorption by mechanisms other than $\mathrm{ENaC}$.

Copyright $\odot 2009$ S. Karger AG, Basel

\section{Introduction}

Serum- and glucocorticoid-inducible kinase 1 (SGK1) was originally cloned as a glucocorticoid-inducible gene [1] and was subsequently found to be involved in the signal transduction pathway of the mineralocorticoid aldosterone [2]. SGK1 is expressed in the aldosterone-sensitive distal nephron [3] and stimulates the heterologously expressed epithelial sodium channel (ENaC) [4-6]. Moreover, in vitro experiments revealed the ability of SGK1 to stimulate a wide variety of further channels and transporters [7-14], including the renal outer medullary $\mathrm{K}^{+}$ 
channel $1[15], \mathrm{Na}^{+} / \mathrm{H}^{+}$exchanger NHE3 $[16,17], \mathrm{Na}^{+}-\mathrm{K}^{+}$$2 \mathrm{Cl}^{-}$cotransporter (NKCC2) [18] and $\mathrm{Na}^{+} / \mathrm{K}^{+}$-ATPase $[19,20]$.

The physiological significance of SGK1 in the regulation of renal salt excretion became apparent from the comparison of gene-targeted mice lacking SGK1 ( $\left.s g k 1^{-/}\right)$ and their wild-type littermates $\left(s g k 1^{+/+}\right)$. Renal $\mathrm{Na}^{+}$retention is moderately impaired in $s g k 1^{-/-}$mice $[21,22]$, which contrasts with the severely impaired phenotype of mice lacking functional $\alpha$-ENaC $[23,24], \beta-\mathrm{ENaC}[25], \gamma$ $\mathrm{ENaC}$ [26] or the mineralocorticoid receptor [27]. In $s g k 1^{-/-}$mice, the defective regulation of renal $\mathrm{Na}^{+}$excretion only becomes apparent after exposure to a salt-deficient diet, which unmasks the limited ability of the $s g k 1^{-/-}$mice to decrease their urinary $\mathrm{Na}^{+}$output despite higher plasma aldosterone concentrations [21, 22].

The salt-losing phenotype of the $s g k 1^{-/-}$mice could not be explained on the basis of impaired $\mathrm{ENaC}$ regulation alone. During a low-salt diet, amiloride-sensitive $\mathrm{Na}^{+}$ currents were even greater in $s g k 1^{-/-}$than in $s g k 1^{+/+}$mice [21], presumably a result of enhanced plasma aldosterone concentrations in $\mathrm{sgk1}^{-/-}$mice. Western analysis in those mice revealed decreased expression of the $\mathrm{Na}^{+}-\mathrm{Cl}^{-} \mathrm{Co}-$ transporter (NCC) in $s g k 1^{-/-}$mice, which presumably contributed to renal salt loss in those mice. Beyond that, SGK1 may participate in the regulation of renal salt excretion by modifying further transport mechanisms, such as NHE3 or NKCC2 [10].

The deranged regulation of renal tubular $\mathrm{Na}^{+}$transport in $s g k 1^{-/-}$mice is expected to impact on the effects of diuretics. By inducing volume and $\mathrm{Na}^{+}$losses, diuretics cause counter-regulatory changes in sympathetic nerve activity, hormone secretion and the kidney itself, which involves up-regulation of the abundance of $\mathrm{Na}^{+}$channels both at the site of diuretic action as well as at distal sites $[28,29]$. The latter can be attributed to the activation of the renin-angiotensin axis and secondary hyperaldosteronism [30,31], which is expected to involve the activation of SGK1. If SGK1 influences renal salt excretion exclusively through stimulation of $\mathrm{ENaC}$, pharmacological inhibition of $\mathrm{ENaC}$ should dissipate the differences between $s g k 1^{-/-}$and $s g k 1^{+/+}$mice. If, however, SGK1-dependent regulation of further $\mathrm{Na}^{+}$transport systems is critical for renal $\mathrm{Na}^{+}$retention, the salt-losing phenotype of $s g k 1^{-/-}$mice would be compounded by the inhibition of $\mathrm{ENaC}$.

The present study thus aimed to define the potency of the diuretics triamterene, furosemide, canrenoate and hydrochlorothiazide in $s g k 1^{-/-}$and $s g k 1^{+/+}$mice.

\section{Methods}

\section{Animal Experiments}

Experiments were performed on SGK1 knockout mice ( $\mathrm{sgk1^{-/- } )}$ and their wild-type littermates $\left(s g k 1^{+/+}\right)$maintained on a 129S1/ SvImJ background with minor genetic contamination from $\mathrm{C} 57 \mathrm{Bl} / 6$. The mice were bred as described elsewhere [22]. Mice were kept on a 12:12 light-dark cycle and fed a standard diet (C1310, Altromin, Lage, Germany; measured $\mathrm{Na}^{+}$content $123 \mu \mathrm{mol} / \mathrm{g}$ food, $\mathrm{Cl}^{-} 100 \mu \mathrm{mol} / \mathrm{g}$ food, $\mathrm{K}^{+} 282 \mu \mathrm{mol} / \mathrm{g}$ food) with tap water (measured $\mathrm{Na}^{+}$content $0.8 \mathrm{mM}$ ) ad libitum. All animal experiments were conducted according to the guidelines of the American Physiological Society as well as laws governing the welfare of animals in Germany, and were approved by the local authorities.

Mice were studied for 2 days on tap water for the determination of the baseline (control) values and then subsequently for 8 days on diuretic treatment. Two to 3 series consisting of $6 \mathrm{sgk1^{-/- }}$ and $6 s g k 1^{+/+}$mice, respectively, were studied under each treatment. Series using different drugs were performed consecutively. Diuretics were supplied in the drinking water without any electrolyte supplementation. Furosemide $(125 \mathrm{mg} / \mathrm{l})$ was applied to block NKCC2 in the loop of Henle, hydrochlorothiazide was applied (400 mg/l, pH 4.5) to block NCC of the early distal tubule, triamterene $(200 \mathrm{mg} / \mathrm{l}, \mathrm{pH} 3)$ was applied to block the epithelial sodium channel $(\mathrm{ENaC})$ of the late distal tubule, and canrenoate $(800 \mathrm{mg} / \mathrm{l})$ was applied to block the mineralocorticoid receptor. A control series delivering tap water at $\mathrm{pH} 3$ was tolerated well without signs of reduced well-being or weight loss. The drugs were delivered in light-protected bottles.

Blood samples were drawn prior to and at the end of diuretic treatment by puncturing the right retro-orbital plexus under light anesthesia with diethyl ether.

\section{Measurements}

Plasma concentrations of $\mathrm{Na}^{+}$and $\mathrm{K}^{+}$were measured by flame photometry (AFM 5051, Eppendorf, Germany). Plasma urea was measured by an enzymatic method (Lehmann, Berlin, Germany). Plasma aldosterone was measured using a RIA kit (Demeditec, Kiel, Germany).

\section{Quantitative RT-PCR}

To quantify SGK1 transcript levels in the kidney, $s g k 1^{+/+}$mice were killed after 8 days of diuretic or control treatment, and the kidneys were removed and rapidly frozen in liquid nitrogen $(\mathrm{n}=$ 6-8 each). Automated disruption and homogenization of frozen tissue of whole kidneys was performed using the MagNa Lyser Instrument ${ }^{\mathrm{TM}}$ (Roche Diagnostics, Mannheim, Germany). Cleared cell lysate was transferred for further RNA purification (RNAeasy Mini Kit, Qiagen, Hilden, Germany). Subsequently, $1 \mu \mathrm{g}$ of total RNA was reverse transcribed to cDNA utilizing the reverse transcription system (Bioscience, USA) with oligo(dT) primers according to the manufacturer's protocol. To determine SGK1 transcript levels, quantitative real-time PCR was applied with the LightCycler System ${ }^{\circledR}$ (Roche Diagnostics, Mannheim, Germany) using the primers 5'-TGTCTTGGGGCTGTCCTGTATG-3' (forward) and 5'-GCTTCTGCT GCTTCCTTCACAC-3' (reverse) for murine SGK1, yielding a product of $406 \mathrm{bp}$. $\mathrm{PCR}$ reactions were performed in a final volume of $20 \mu \mathrm{l}$ containing $2 \mu \mathrm{l} \mathrm{cDNA}, 2.4 \mu \mathrm{l} \mathrm{MgCl}_{2}(3 \mu \mathrm{M}), 1 \mu \mathrm{l}$ primer mix $(0.5 \mu \mathrm{M}$ of both primers), $2 \mu \mathrm{l}$ cDNA Master SYBR Green I mix (Roche Mo- 
lecular Biochemicals, Mannheim, Germany), and 12.6 $\mu$ l DEPCtreated water. The transcript levels of the housekeeping gene GAPDH were determined for each sample using a commercial primer kit (Search LC, Heidelberg, Germany). PCR reactions for GAPDH were performed in a final volume of $20 \mu$ l containing 2 $\mu \mathrm{l}$ cDNA, $2 \mu \mathrm{l}$ primer mix (Search LC), $2 \mu \mathrm{l}$ cDNA Master SYBR Green I mix (Roche Molecular Biochemicals) and $14 \mu$ DEPCtreated water. The target DNA was amplified during 35 cycles of $95^{\circ} \mathrm{C}$ for $10 \mathrm{~s}, 68^{\circ} \mathrm{C}$ for $10 \mathrm{~s}$ and $72^{\circ} \mathrm{C}$ for $16 \mathrm{~s}$; each with a temperature transition rate of $20^{\circ} \mathrm{C} / \mathrm{s}$, a secondary target temperature of $58^{\circ} \mathrm{C}$ and a step size of $0.5^{\circ} \mathrm{C}$. A melting curve analysis was performed at $95^{\circ} \mathrm{C}$ for $0 \mathrm{~s}, 58^{\circ} \mathrm{C}$ for $10 \mathrm{~s}$, and $95^{\circ} \mathrm{C}$ for $0 \mathrm{~s}$ to determine the melting temperatures of primer dimers and the specific PCR products. A melting curve analysis confirmed the amplified products. Finally, results were calculated as a ratio of the target versus the housekeeping gene GAPDH transcripts.

\section{Immunofluorescence}

For the analysis of SGK1 protein expression in the kidney, $s g k 1^{+/+}$mice were killed after 8 days of diuretic or control treatment, and the kidneys were rapidly frozen in liquid nitrogen $(\mathrm{n}=$ $2 s g k 1^{+/+}$mice each). Frozen sections of whole kidneys without microdissection $(3 \mu \mathrm{m})$ were fixed in acetone $\left(10 \mathrm{~min}\right.$ at $\left.-20^{\circ} \mathrm{C}\right)$, air dried and stored in a Tris buffer for $5 \mathrm{~min}$. Then blocking was performed with normal goat serum (blotto, 1:5, $45 \mathrm{~min}$ ). Afterwards, the primary antibody (rabbit anti-SGK1, 1:50) was applied $\left(1 \mathrm{~h}, 37^{\circ} \mathrm{C}\right)$ and the sections were washed in Tris buffer $(3 \times$ $5 \mathrm{~min}$ ). Polyclonal monospecific antibodies against the SGK1 protein were raised by a commercial antibody service (Dr. Pineda, Berlin, Germany) as described elsewhere [32]. Previous studies had shown that the target detected by this antibody colocalized with $11 \beta$-steroid dehydrogenase type 2 indicating the aldosterone-sensitive distal nephron [33]. Afterwards the secondary antibody (goat anti-rabbit, Alexa 488, 1:200) was applied for $30 \mathrm{~min}$. DAPI was used to stain nuclei (1:1,000 in distilled water for $5 \mathrm{~min}$ ), followed by rinsing in Tris buffer $(3 \times 5 \mathrm{~min})$. Finally, sections were covered with Mowiol and analyzed.

\section{Statistics}

Data are provided as arithmetic means \pm SEM; $n$ represents the number of independent experiments. All data were tested for significance with a parametric or non-parametric unpaired Student's t test or Mann-Whitney test where applicable, using GraphPad InStat (GraphPad Software, San Diego, Calif., USA). p $<0.05$ was considered statistically significant.

\section{Results}

As analyzed by immunofluorescence, the treatment of wild-type animals with each of the diuretic drugs significantly increased SGK1 protein expression (fig. 1a). Diuretic treatment led to the recruitment of additional renal tubules expressing appreciable levels of SGK1, i.e. the portion of the nephron regulated by SGK1 increased following diuretic induced fluid loss. According to quantitative RT-PCR, treatment was followed by a significant increase of the SGK1 transcript levels to similar values following an 8-day treatment with triamterene, furosemide, canrenoate and hydrochlorothiazide (fig. 1b). Kidneys from $s g k 1^{-/-}$mice did not express intact SGK1 mRNA.

During diuretic treatment, the calculated mean daily drug intake for furosemide, canrenoate and hydrochlorothiazide was not different between SGK1 knockout mice $\left(s g k 1^{-/-}\right)$and their wild-type littermates $\left(s g k 1^{+/+}\right)$, triamterene intake was slightly reduced in $s g k 1^{-/-}$mice (fig. 2a). Under control conditions, food and fluid intake was similar in $s g k 1^{-/-}$and $s g k 1^{+/+}$mice (fig. $2 \mathrm{~b}, \mathrm{c}$ ). Food intake remained constant under treatment with triamterene and canrenoate (fig. 2b). It increased slightly following treatment with furosemide and hydrochlorothiazide, reaching statistical significance in $s g k 1^{+/+}$mice. Under treatment with furosemide, fluid intake increased in both genotypes (fig. 2c). Under treatment with triamterene, fluid intake was slightly, but significantly, lower in $s g k 1^{-/-}$mice compared to $s g k 1^{+/+}$mice. Under treatment with canrenoate or hydrochlorothiazide, fluid intake was not altered significantly in either genotype. It is possible that the effects of thirst and the taste of the drugcontaining drinking water were partially counteractive.

Body weight was measured to assess the volume loss during diuretic treatment. As shown in figure $2 \mathrm{~d}$, body weight loss under diuretic treatment was moderate $(<1.5 \mathrm{~g})$ in $s g k 1^{+/+}$mice, irrespective of the diuretic drug used. The weight loss of $s g k 1^{-/-}$mice was similarly low following diuretic treatment with furosemide, canrenoate and hydrochlorothiazide. In contrast, triamterene caused massive body weight loss in $s g k 1^{-/-}$mice reaching $-4.2 \pm 0.8 \mathrm{~g}$ after 8 days. During the treatment, 5 of 12 $s g k 1^{-/-}$mice died, pointing to a severe disorder of electrolyte balance.

At control conditions, plasma sodium and potassium concentrations were similar in both genotypes and remained largely constant in both genotypes during treatment with furosemide, hydrochlorothiazide and canrenoate. In contrast, triamterene led to marked hyperkalemia in $s g k 1^{-/-}$mice, but not in $s g k 1^{+/+}$mice (fig. 3).

The alterations of body weight and plasma $\mathrm{K}^{+}$concentration reflect alterations in renal fluid and electrolyte loss, as - with the exception of furosemide treatment fluid and food intake were only slightly modified by diuretic treatment. Even in the absence of diuretic treatment, daily fluid intake and urinary output may approach $5-15 \%$ of body weight in mice. Thus, even a moderate imbalance between intake and urinary output of fluid and electrolytes is followed by marked alterations in body weight and plasma electrolyte concentrations. 

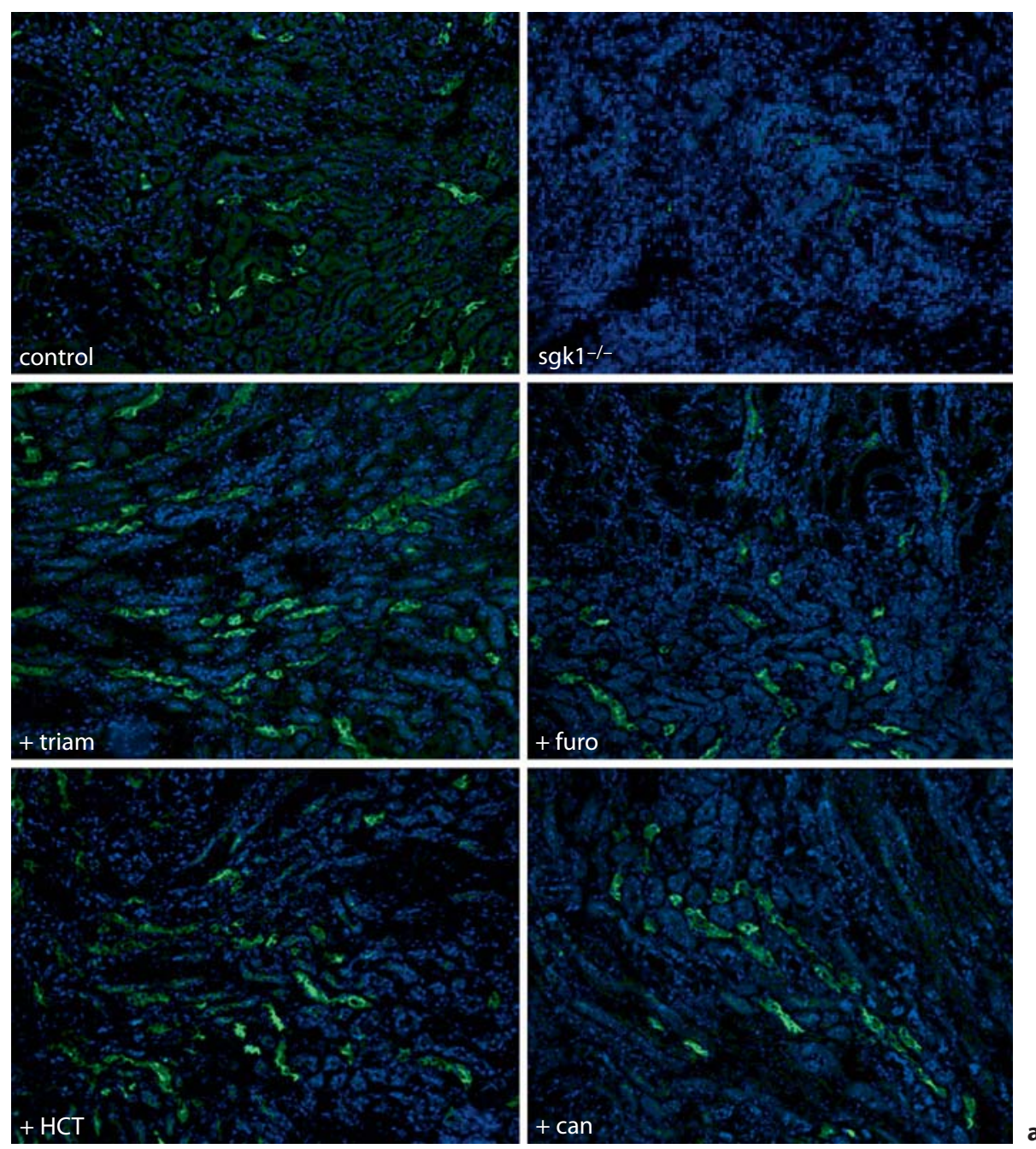

Fig. 1. SGK1 protein and mRNA expression during diuretic treatment of the SGK1 protein (a) and mRNA (b) expression in whole kidneys of wild-type mice analyzed by immunofluorescence and quantitative RT-PCR after 8 days of diuretic treatment $(n=6-8$ each). Green fluorescence represents SGK1, blue represents DAPI-stained nuclei. SGK1 mRNA expression was normalized to the housekeeping gene GAPDH. " Significant difference to the control value.

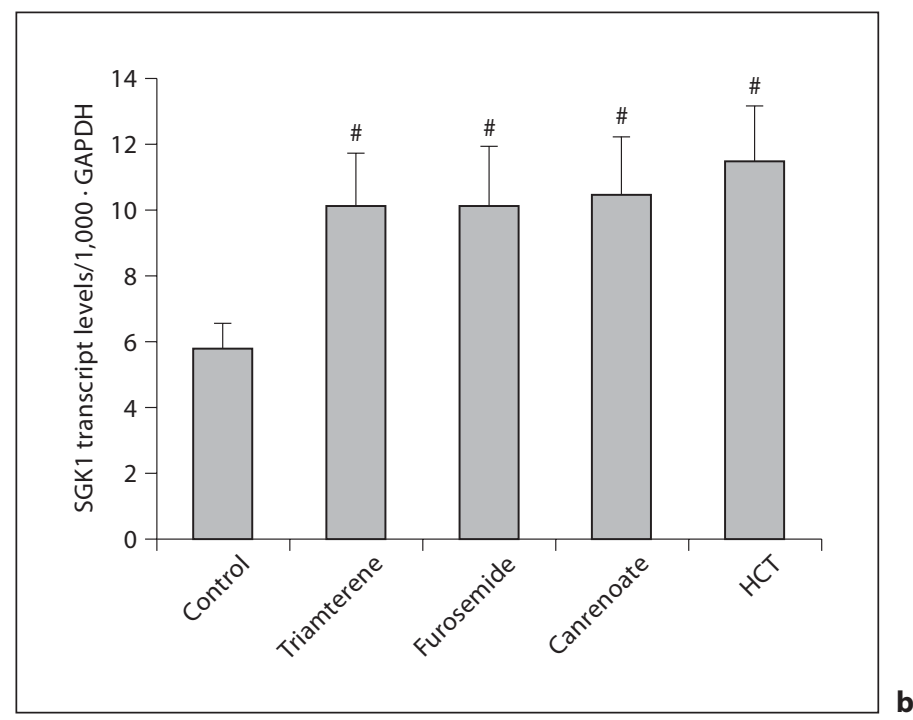




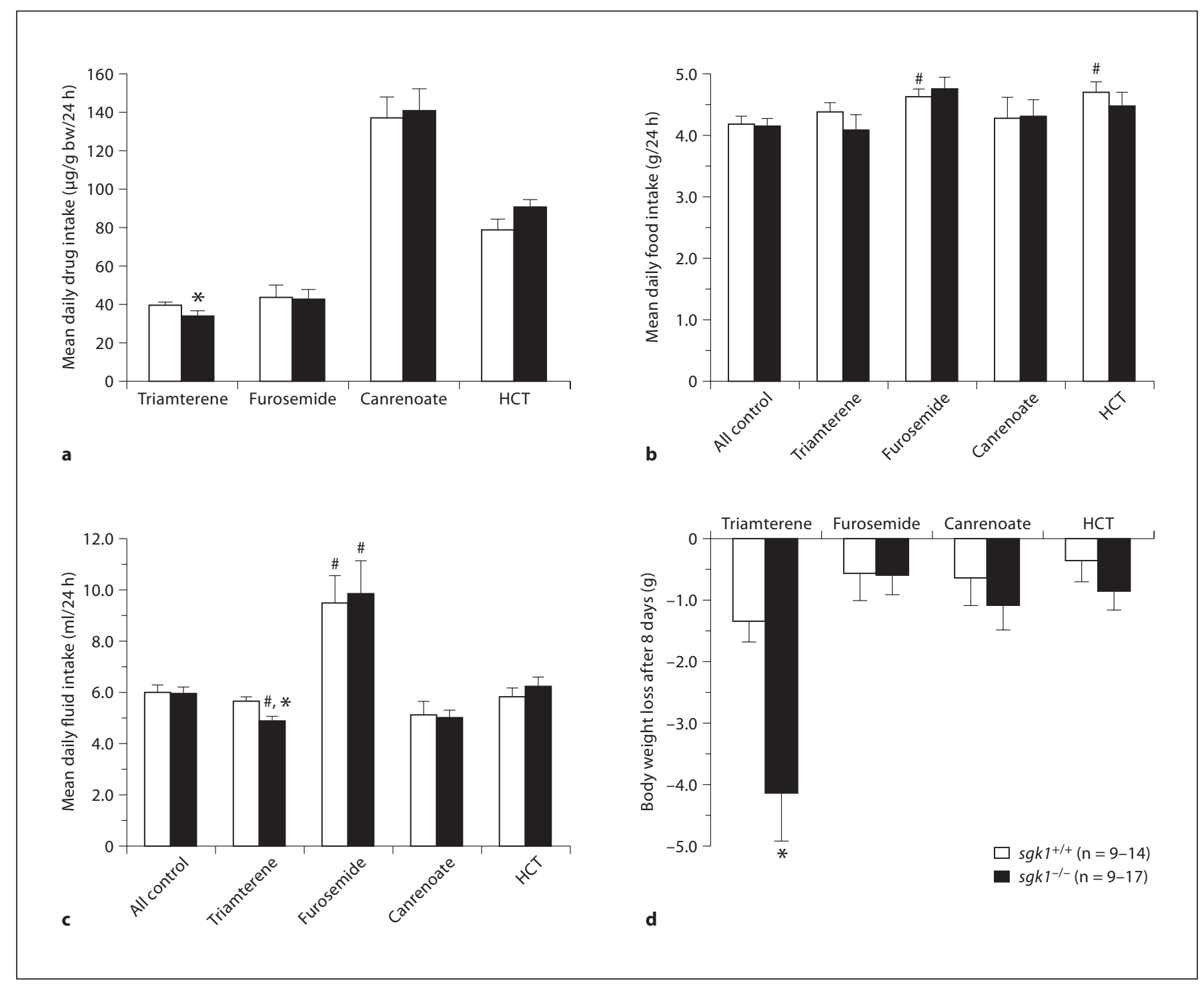

Fig. 2. Daily drug, food and fluid intake as well as body weight change during diuretic treatment. Arithmetic means \pm SEM of daily drug (a), food (b) and fluid intake (c) as well as change of body weight (d) in $s g k 1^{-/-}$mice (closed bars, $\mathrm{n}=9-17)$ and their wild-type littermates $\left(s g k 1^{+/+}\right.$, open bars, $\left.\mathrm{n}=9-14\right)$. Baseline values from all series were pooled to obtain control values designated as 'all controls'. " Significant difference to control; * significant difference between $s g k 1^{-/-}$and $s g k 1^{+/+}$mice.

Prior to diuretic treatment, plasma aldosterone concentrations were significantly higher in $s g k 1^{-/-}$than in $s g k 1^{+/+}$mice. In $s g k 1^{+/+}$mice, treatment with furosemide, hydrochlorothiazide and canrenoate tended to increase plasma aldosterone concentrations, an effect which did not reach statistical significance. In $s g k 1^{-/-}$mice, diuretic treatment similarly increased plasma aldosterone concentrations. This effect reached statistical significance during treatment with furosemide and hydrochlorothia- zide, but not during treatment with canrenoate (fig. 4a). Under triamterene treatment, plasma aldosterone concentrations increased in both $s g k 1^{+/+}$and $s g k 1^{-/-}$mice, an effect significantly more pronounced in $s g k 1^{-/-}$mice.

Under control conditions, plasma urea concentrations tended to be higher in $s g k 1^{-/-}$and $s g k 1^{+/+}$mice. This difference, however, did not reach statistical significance (fig. 4b). During diuretic treatment with furosemide, hydrochlorothiazide and canrenoate, plasma urea con- 


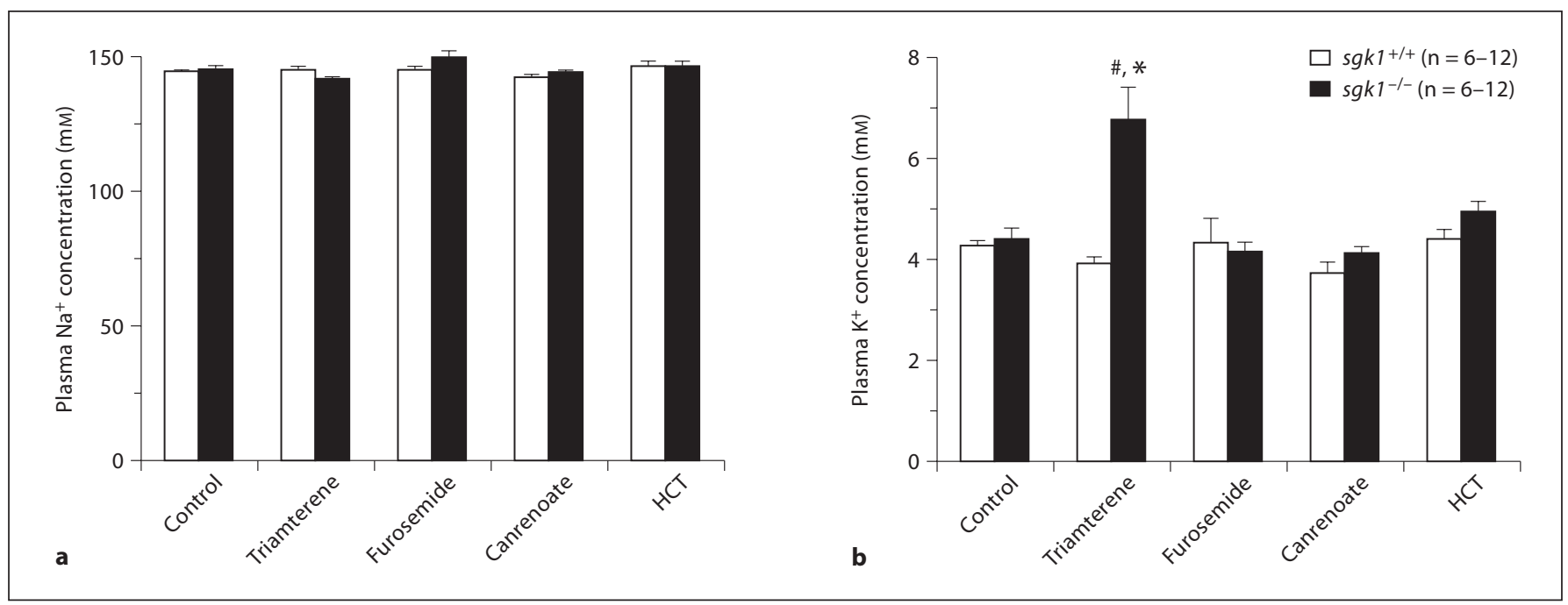

Fig. 3. Effect of diuretic treatment on plasma $\mathrm{Na}^{+}$and $\mathrm{K}^{+}$concentrations. Arithmetic means \pm SEM of plasma $\mathrm{Na}^{+}(\mathbf{a})$ and $\mathrm{K}^{+}$concentrations (b) in $s g k 1^{-/-}$mice (closed bars, $\left.\mathrm{n}=6-12\right)$ and their wild-type littermates $\left(s g k 1^{+/+}\right.$, open bars, $\mathrm{n}=6-12)$. " Significant difference to the control value; * significant difference between the genotypes.

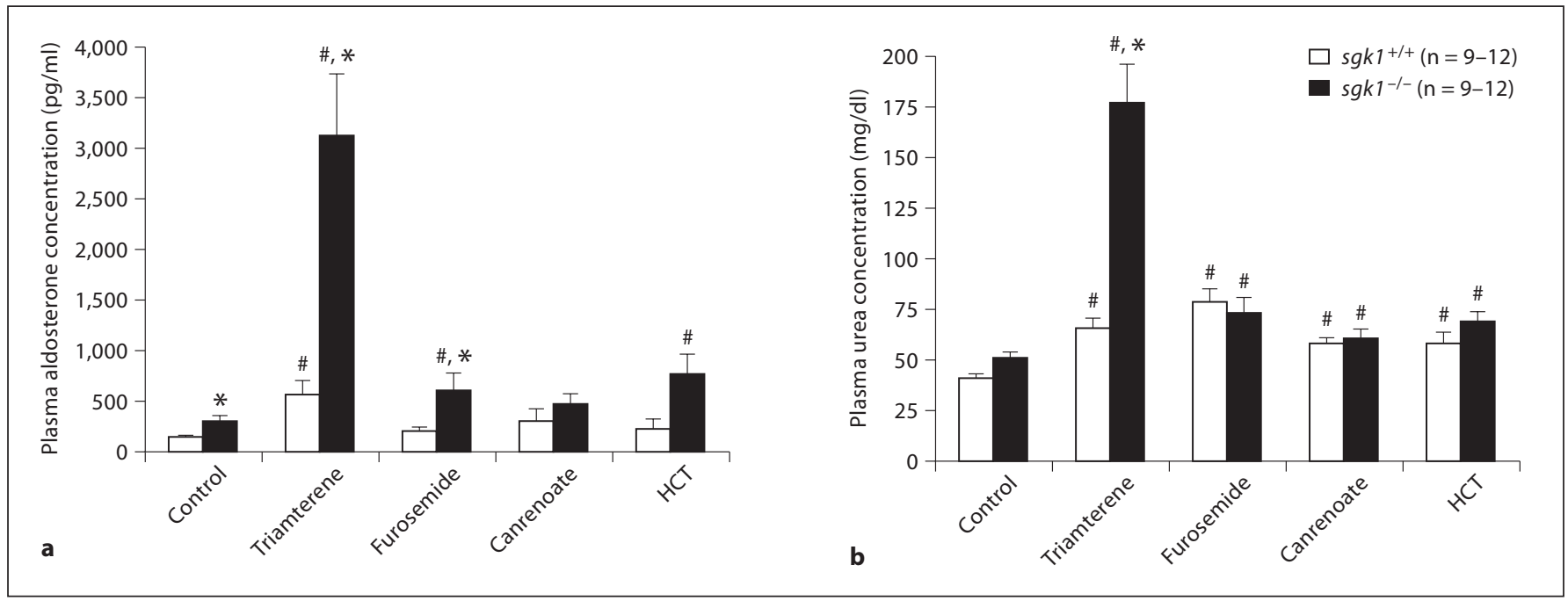

Fig. 4. Plasma aldosterone and urea concentrations during diuretic treatment. Arithmetic means \pm SEM of plasma aldosterone concentrations (a) and plasma urea concentrations (b) after 8 days of diuretic treatment in $s g k 1^{-/-}$mice (closed bars, $\left.\mathrm{n}=9-12\right)$ and their wild-type littermates $\left(s g k 1^{+/+}\right.$, open bars, $\left.\mathrm{n}=9-12\right)$. ${ }^{\text {S Significant }}$ difference to the control value; * significant difference between $s g k 1^{-l-}$ and $s g k 1^{+/+}$mice.

centrations increased significantly to similar values in $s g k 1^{-/-}$and $s g k 1^{+/+}$mice. Following the treatment of $s g k 1^{+/+}$ mice with triamterene, the urea concentration increased significantly to values similar to those following treatment with the other diuretic drugs. In contrast, following the treatment of $s g \mathrm{kl}^{-/-}$mice with triamterene, the urea concentration increased to values significantly higher than those observed in $s g k 1^{-1-}$ mice following treatment with the other diuretic drugs or in $s g k 1^{+/+}$mice following treatment with any diuretic drug. 


\section{Discussion}

The present study shows that diuretic treatment with triamterene induces severe salt-wasting, hyperkalemia and death in gene-targeted mice lacking functional SGK1 $\left(s g k 1^{--}\right)$, indicating that SGK1 is critically required for the maintenance of electrolyte balance during pharmacological inhibition of $\mathrm{ENaC}$. In contrast, diuretic treatment with furosemide, hydrochlorothiazide or canrenoate was tolerated similarly well in $s g k 1^{-/-}$mice as in their wild-type littermates $\left(s g k 1^{+++}\right)$. These results are surprising in view of the well-known role of SGK1 in the regulation of ENaC [4-6]. If the renal tubular effect of SGK1 was restricted to upregulation of $\mathrm{ENaC}$, pharmacological inhibition of $\mathrm{ENaC}$ would be expected to dissipate the differences between $s g k 1^{-/-}$and $s g k 1^{+/+}$mice. The opposite has been observed, indicating that $s g k 1^{-1-}$ mice are critically dependent on $\mathrm{ENaC}$ activity for the maintenance of their electrolyte balance. The present experiments cannot rule out the possibility that triamterene and the lack of SGK1 exert additive effects on $\mathrm{ENaC}$ activity leading to a more complete inhibition of $\mathrm{ENaC} \mathrm{ac}$ tivity than either triamterene treatment or a lack of SGK1 alone. Moreover, the present data do not rule out the possibility that triamterene decreases body weight and compromises survival of $s g k 1^{-/-}$mice by mechanisms other than inhibiting ENaC. Nevertheless, the present observations may point to a critical role for SGK1-dependent renal $\mathrm{Na}^{+}$reabsorption other than $\mathrm{ENaC}$.

The latter possibility is supported by a recent study, which provided convincing evidence for SGK1-dependent stimulation of renal $\mathrm{Na}^{+}$reabsorption involving transport systems other than $\mathrm{ENaC}$ [21]. In this study, amiloride-sensitive $\mathrm{Na}^{+}$currents in isolated collecting ducts were not reduced in $s g k 1^{-/-}$mice [21]. Under a lowsalt diet, amiloride-sensitive $\mathrm{Na}^{+}$currents were found to be even higher in $s g k 1^{-/-}$than in $s g k 1^{+/+}$mice [21]. The renal $\mathrm{Na}^{+}$loss may have been partially due to decreased expression of the NCC rather than to impaired $\mathrm{ENaC} \mathrm{ac}-$ tivity [21]. Along those lines, amiloride-sensitive $\mathrm{Na}^{+}$ currents across the colonic epithelium were significantly higher in $s g k 1^{-/-}$than in $s g k 1^{+/+}$mice [34]. Regulation of $\mathrm{ENaC}$ by mineralocorticoids is not critically dependent on SGK1, but can be circumvented by enhanced expression of the channel protein. Aldosterone rescues the mice via $\mathrm{ENaC}$ activation also, especially in the absence of SGK1. SGK1 is critically important for the stimulation of $\mathrm{ENaC}$ by insulin, and renal $\mathrm{Na}^{+}$excretion is lowered following insulin infusion in $s g k 1^{+/+}$mice but not in $s g k 1^{-/-}$ mice $[35,36]$.

Triamterene Hypersensitivity of SGK1-Deficient Mice
According to a previous study [33], the deleterious effects of triamterene in $s g k 1^{-/}$mice were attenuated during concomitant treatment with the peroxisome proliferator-activated receptor- $\gamma$ (PPAR- $\gamma$ ) agonist pioglitazone. In that study, mean body weight loss was only $-1.6 \mathrm{~g}$ after 8 days without any deaths in $s g k 1^{-/-}$mice. This finding may result from the volume retaining effects of pioglitazone, which are only partially dependent on SGK1 [33]. PPAR- $\gamma$ activation has been said to involve direct genomic upregulation of $\mathrm{ENaC}$ [37], which, however, would again be inhibited by triamterene. Pioglitazone may have an influence on renal $\mathrm{Na}^{+}$excretion through its genomic regulation of further renal transport systems.

The death of $\mathrm{sgk1}^{-/-}$mice following triamterene treatment may have been due to volume depletion leading to acute prerenal failure complicated by severe hyperkalemia. The excessive hyperkalemia may be exacerbated by the critical role of SGK1 in the regulation of $\mathrm{K}^{+}$excretion [38]. The ability of $s g k 1^{-/-}$mice to excrete an acute $\mathrm{K}^{+}$load is impaired despite increased basal plasma aldosterone concentrations [38]. Moreover, sgk $1^{-/}$mice require marked increases of plasma $\mathrm{K}^{+}$and aldosterone concentrations to excrete a chronic $\mathrm{K}^{+}$load [38]. The impaired ability of $s g k 1^{-/-}$mice to eliminate a $\mathrm{K}^{+}$load may be related to its role in (1) the regulation of the renal outer medullary $\mathrm{K}^{+}$channel or some other renal epithelial $\mathrm{K}^{+}$ channel, (2) decreased electrical driving force secondary to decreased $\mathrm{ENaC}$ activity and/or (3) $\mathrm{Na}^{+} / \mathrm{K}^{+}$-ATPase activity. Besides its role in the regulation of renal $\mathrm{K}^{+}$elimination, SGK1 is critically important for the stimulation of cellular $\mathrm{K}^{+}$uptake by insulin [39].

Diuretic tolerance occurs during long-term treatment with any diuretic. This leads to a new steady state at a reduced extracellular volume, accounted for by reduced body weight. Various counter regulatory mechanisms are involved in mediating diuretic tolerance such as the activation of the renin-angiotension-system and secondary hyperaldosteronism, increased sympathetic activity and the release of vasopressin [30,31]. At the level of the renal tubules, the abundance of $\mathrm{Na}^{+}$channels, both at the site of diuretic action and at distal sites, are increased [28]. Western blot studies have shown an increase in $\mathrm{ENaC}$ membrane abundance during treatment with furosemide, thiazide or amiloride in rats [29] which might involve activation of SGK1. The present data indicate that diuretic treatment is indeed followed by upregulation of SGK1 transcription involving a larger number of tubules. However, the lack of SGK1 was only limiting during triamterene treatment, not during treatment with furose- 
mide or thiazide, which points to an intact $\mathrm{ENaC}$ upregulation without SGK1.

Plasma aldosterone levels are invariably increased in $s g k 1^{-1-}$ mice even under a controlled diet $[21,22]$. However, blockade of the mineralocorticoid receptor by canrenoate did not lead to a stronger natriuretic effect in $s g k 1^{-/-}$mice. Thus, mineralocorticoid receptors may not be critically important for the fluid retention in $s g k 1^{-/}$ mice. It should be kept in mind that the function of $\mathrm{ENaC}$ is not exclusively dependent on functional mineralocorticoid receptors, as residual $\mathrm{ENaC}$ activity was observed in gene-targeted mice lacking functional mineralocorticoid receptors [27].

The present observations strongly suggest that SGK1 is not only involved in the regulation of $\mathrm{ENaC}$, but also influences further renal tubular $\mathrm{Na}^{+}$transport systems.
Candidate systems include NHE3 [16, 17], NKCC2 [18], NCC [21] and $\mathrm{Na}^{+} / \mathrm{K}^{+}$-ATPase $[19,20]$. The use of diuretics cannot, however, lead to an unequivocal definition of the transport systems, as the inhibition of any system will be paralleled by upregulation of other systems [28].

In conclusion, SGK1 is critically required for diuretic tolerance to triamterene. Accordingly, mice deficient in SGK1 seem to be critically dependent on residual ENaC activity.

\section{Acknowledgments}

We are grateful to Miriam Reutelshöfer for her work with the immunofluorescence. We also thank Andrea Janessa for the PCR measurements and Florian Grahammer for discussions.

\section{References}

1 Webster MK, Goya L, Ge Y, Maiyar AC, Firestone GL: Characterization of sgk, a novel member of the serine/threonine protein kinase gene family which is transcriptionally induced by glucocorticoids and serum. Mol Cell Biol 1993;13:2031-2040.

2 Bhargava A, Fullerton MJ, Myles K, Purdy TM, Funder JW, Pearce D, Cole TJ: The serum- and glucocorticoid-induced kinase is a physiological mediator of aldosterone action. Endocrinology 2001;142:1587-1594.

3 Loffing J, Zecevic M, Feraille E, Kaissling B, Asher C, Rossier BC, Firestone GL, Pearce D, Verrey F: Aldosterone induces rapid apical translocation of $\mathrm{ENaC}$ in early portion of renal collecting system: possible role of SGK. Am J Physiol Renal Physiol 2001;280:F675F682.

4 Chen SY, Bhargava A, Mastroberardino L, Meijer OC, Wang J, Buse P, Firestone GL, Verrey F, Pearce D: Epithelial sodium channel regulated by aldosterone-induced protein sgk. Proc Natl Acad Sci USA 1999;96: 2514-2519.

5 Naray-Fejes-Toth A, Canessa C, Cleaveland ES, Aldrich G, Fejes-Toth G: sgk is an aldosterone-induced kinase in the renal collecting duct: effects on epithelial $\mathrm{Na}^{+}$channels. J Biol Chem 1999;274:16973-16978.

6 Shigaev A, Asher C, Latter H, Garty H, Reuveny E: Regulation of sgk by aldosterone and its effects on the epithelial $\mathrm{Na}(+)$ channel. Am J Physiol Renal Physiol 2000;278: F613-F619.
7 Boehmer C, Palmada M, Klaus F, Jeyaraj S, Lindner R, Laufer J, Daniel H, Lang F: The peptide transporter PEPT2 is targeted by the protein kinase SGK1 and the scaffold protein NHERF2. Cell Physiol Biochem 2008;22. 705-714.

8 Boehmer C, Laufer J, Jeyaraj S, Klaus F, Lindner R, Lang F, Palmada M: Modulation of the voltage-gated potassium channel Kv1.5 by the SGK1 protein kinase involves inhibition of channel ubiquitination. Cell Physiol Biochem 2008;22:591-600.

9 Jeyaraj S, Boehmer C, Lang F, Palmada M: Role of SGK1 kinase in regulating glucose transport via glucose transporter GLUT4. Biochem Biophys Res Commun 2007;356: 629-635.

10 Lang F, Bohmer C, Palmada M, Seebohm G, Strutz-Seebohm N, Vallon V: (Patho)physiological significance of the serum- and glucocorticoid-inducible kinase isoforms. Physiol Rev 2006;86:1151-1178.

11 Rajamanickam J, Palmada M, Lang F, Boehmer C: EAAT4 phosphorylation at the SGK1 consensus site is required for transport modulation by the kinase. J Neurochem 2007;102:858-866.

12 Sato JD, Chapline MC, Thibodeau R, Frizzell RA, Stanton BA: Regulation of human cystic fibrosis transmembrane conductance regulator (CFTR) by serum- and glucocorticoidinducible kinase (SGK1). Cell Physiol Biochem 2007;20:91-98.

13 Shaw JR, Sato JD, VanderHeide J, LaCasse T, Stanton CR, Lankowski A, Stanton SE, Chapline C, Coutermarsh B, Barnaby R, Karlson $\mathrm{K}$, Stanton BA: The role of SGK and CFTR in acute adaptation to seawater in Fundulus heteroclitus. Cell Physiol Biochem 2008;22: 69-78.
14 Strutz-Seebohm N, Shojaiefard M, Christie D, Tavare J, Seebohm G, Lang F: PIKfyve in the SGK1 mediated regulation of the creatine transporter SLC6A8. Cell Physiol Biochem 2007;20:729-734.

15 Yun CC, Palmada M, Embark HM, Fedorenko O, Feng Y, Henke G, Setiawan I, Boehmer C, Weinman EJ, Sandrasagra S, Korbmacher C, Cohen P, Pearce D, Lang F: The serum and glucocorticoid-inducible kinase SGK1 and the $\mathrm{Na}^{+} / \mathrm{H}^{+}$exchange regulating factor NHERF2 synergize to stimulate the renal outer medullary $\mathrm{K}^{+}$channel ROMK1. J Am Soc Nephrol 2002;13:2823-2830.

16 Wang D, Zhang H, Lang F, Yun CC: Acute activation of NHE3 by dexamethasone correlates with activation of SGK1 and requires a functional glucocorticoid receptor. Am J Physiol Cell Physiol 2007;292:C396-C404.

17 Yun CC, Chen Y, Lang F: Glucocorticoid activation of $\mathrm{Na}(+) / \mathrm{H}(+)$ exchanger isoform 3 revisited. The roles of SGK1 and NHERF2. J Biol Chem 2002;277:7676-7683.

18 Lang F, Klingel K, Wagner CA, Stegen C, Warntges S, Friedrich B, Lanzendorfer M, Melzig J, Moschen I, Steuer S, Waldegger S, Sauter M, Paulmichl M, Gerke V, Risler T, Gamba G, Capasso G, Kandolf R, Hebert SC, Massry SG, Broer S: Deranged transcriptional regulation of cell-volume-sensitive kinase hSGK in diabetic nephropathy. Proc Natl Acad Sci USA 2000;97:8157-8162.

19 Setiawan I, Henke G, Feng Y, Bohmer C, Vasilets LA, Schwarz W, Lang F: Stimulation of Xenopus oocyte $\mathrm{Na}(+), \mathrm{K}(+)$ ATPase by the serum and glucocorticoid-dependent kinase sgk1. Pflügers Arch 2002;444:426-431. 
20 Zecevic M, Heitzmann D, Camargo SM, Verrey F: SGK1 increases Na,K-ATP cell-surface expression and function in Xenopus laevis oocytes. Pflugers Arch 2004;448:29-35.

21 Fejes-Toth G, Frindt G, Naray-Fejes-Toth A, Palmer LG: Epithelial $\mathrm{Na}+$ channel activation and processing in mice lacking SGK1. Am J Physiol Renal Physiol 2008;294:F1298F1305.

22 Wulff P, Vallon V, Huang DY, Volkl H, Yu F, Richter K, Jansen M, Schlunz M, Klingel K, Loffing J, Kauselmann G, Bosl MR, Lang F, Kuhl D: Impaired renal $\mathrm{Na}(+)$ retention in the sgk1-knockout mouse. J Clin Invest 2002; 110:1263-1268.

23 Hummler E, Barker P, Gatzy J, Beermann F, Verdumo C, Schmidt A, Boucher R, Rossier BC: Early death due to defective neonatal lung liquid clearance in alpha-ENaC-deficient mice. Nat Genet 1996;12:325-328.

24 Hummler E, Barker P, Talbot C, Wang Q, Verdumo C, Grubb B, Gatzy J, Burnier M, Horisberger JD, Beermann F, Boucher R, Rossier BC: A mouse model for the renal saltwasting syndrome pseudohypoaldosteronism. Proc Natl Acad Sci USA 1997;94:1171011715.

25 McDonald FJ, Yang B, Hrstka RF, Drummond HA, Tarr DE, McCray PB Jr, Stokes JB, Welsh MJ, Williamson RA: Disruption of the beta subunit of the epithelial $\mathrm{Na}+$ channel in mice: hyperkalemia and neonatal death associated with a pseudohypoaldosteronism phenotype. Proc Natl Acad Sci USA 1999;96: 1727-1731.
26 Barker PM, Nguyen MS, Gatzy JT, Grubb B, Norman H, Hummler E, Rossier B, Boucher $\mathrm{RC}$, Koller B: Role of gammaENaC subunit in lung liquid clearance and electrolyte balance in newborn mice: insights into perinatal adaptation and pseudohypoaldosteronism. J Clin Invest 1998;102:1634-1640.

27 Berger S, Bleich M, Schmid W, Cole TJ, Peters J, Watanabe H, Kriz W, Warth R, Greger R, Schutz G: Mineralocorticoid receptor knockout mice: pathophysiology of $\mathrm{Na}+\mathrm{me}-$ tabolism. Proc Natl Acad Sci USA 1998;95: 9424-9429.

28 Kim GH: Long-term adaptation of renal ion transporters to chronic diuretic treatment. Am J Nephrol 2004;24:595-605.

$29 \mathrm{Na}$ KY, Oh YK, Han JS, Joo KW, Lee JS, Earm JH, Knepper MA, Kim GH: Upregulation of $\mathrm{Na}^{+}$transporter abundances in response to chronic thiazide or loop diuretic treatment in rats. Am J Physiol Renal Physiol 2003;284: F133-F143.

30 Lant A: Diuretics: clinical pharmacology and therapeutic use. Part II. Drugs 1985;29: $162-188$

31 Lant A: Diuretics: clinical pharmacology and therapeutic use. Part I. Drugs 1985;29: 57-87.

32 Huber SM, Friedrich B, Klingel K, Lenka N, Hescheler J, Lang F: Protein and mRNA expression of serum and glucocorticoid-dependent kinase 1 in metanephrogenesis. Dev Dyn 2001;221:464-469.

33 Artunc F, Sandulache D, Nasir O, Boini KM Friedrich B, Beier N, Dicks E, Potzsch S, Klingel K, Amann K, Blazer-Yost BL, Scholz W, Risler T, Kuhl D, Lang F: Lack of the serum and glucocorticoid-inducible kinase SGK1 attenuates the volume retention after treatment with the PPARgamma agonist pioglitazone. Pflügers Arch 2008;456:425436.
34 Rexhepaj R, Artunc F, Grahammer F, Nasir O, Sandu C, Friedrich B, Kuhl D, Lang F: SGK1 is not required for regulation of colonic $\mathrm{ENaC}$ activity. Pflügers Arch 2006;453: 97-105.

35 Huang DY, Boini KM, Friedrich B, Metzger M, Just L, Osswald H, Wulff P, Kuhl D, Vallon V, Lang F: Blunted hypertensive effect of combined fructose and high-salt diet in gene-targeted mice lacking functional serum- and glucocorticoid-inducible kinase SGK1. Am J Physiol Regul Integr Comp Physiol 2006;290:R935-R944.

36 Huang DY, Boini KM, Osswald H, Friedrich B, Artunc F, Ullrich S, Rajamanickam J, Palmada M, Wulff P, Kuhl D, Vallon V, Lang F: Resistance of mice lacking the serumand glucocorticoid-inducible kinase SGK1 against salt-sensitive hypertension induced by a high-fat diet. Am J Physiol Renal Physiol 2006;291:F1264-F1273.

37 Guan Y, Hao C, Cha DR, Rao R, Lu W, Kohan DE, Magnuson MA, Redha R, Zhang Y, Breyer MD: Thiazolidinediones expand body fluid volume through PPARgamma stimulation of ENaC-mediated renal salt absorption. Nat Med 2005;11:861-866.

38 Huang DY, Wulff P, Volkl H, Loffing J, Richter K, Kuhl D, Lang F, Vallon V: Impaired regulation of renal $\mathrm{K}^{+}$elimination in the sgk1-knockout mouse. J Am Soc Nephrol 2004:15:885-891.

39 Boini KM, Graf D, Kuhl D, Haussinger D, Lang F: SGK1 dependence of insulin induced hypokalemia. Pflügers Arch 2008;457:955961 